\title{
Erratum to mortality prediction algorithms for patients undergoing primary percutaneous coronary intervention
}

\author{
Istvan Hizoh $^{1}$, Dominika Domokos ${ }^{1}$, Gyongyver Banhegyi ${ }^{2}$, David Becker ${ }^{1}$, Bela Merkely ${ }^{1}$, Zoltan Ruzsa ${ }^{1,3}$ \\ ${ }^{1}$ Heart and Vascular Center, Semmelweis University, Budapest, Hungary; ${ }^{2}$ Independent Researcher, Budapest, Hungary; ${ }^{3}$ Department of Invasive \\ Cardiology, Bacs-Kiskun County University Teaching Hospital, Kecskemet, Hungary \\ Correspondence to: Istvan Hizoh, MD, PhD. Heart and Vascular Center, Semmelweis University, Varosmajor u. 68, Budapest 1122, Hungary. \\ Email: istvan.hizoh@alumni.uni-heidelberg.de.
}

doi: $10.21037 /$ jtd-2020-56

View this article at: http://dx.doi.org/10.21037/jtd-2020-56

Erratum to: J Thorac Dis 2020;12:1706-20.

Mortality prediction algorithms for patients undergoing primary percutaneous coronary intervention

This article that appeared on Page: 1706-1720, Vol 12, No 4 (April 2020) Issue of the fournal of Thoracic Disease (FTD) (1), contained ONE mistake.

The detailed correction is as below:

Table 2 was erroneously typeset. In column \#3 ("Source of Data") all cell contain "Multi Center Registry" to the contrary of the submitted "Table 2", which negatively affects the scientific content of the paper.

The corrected version of Table 2 is presented here (Table 2). 


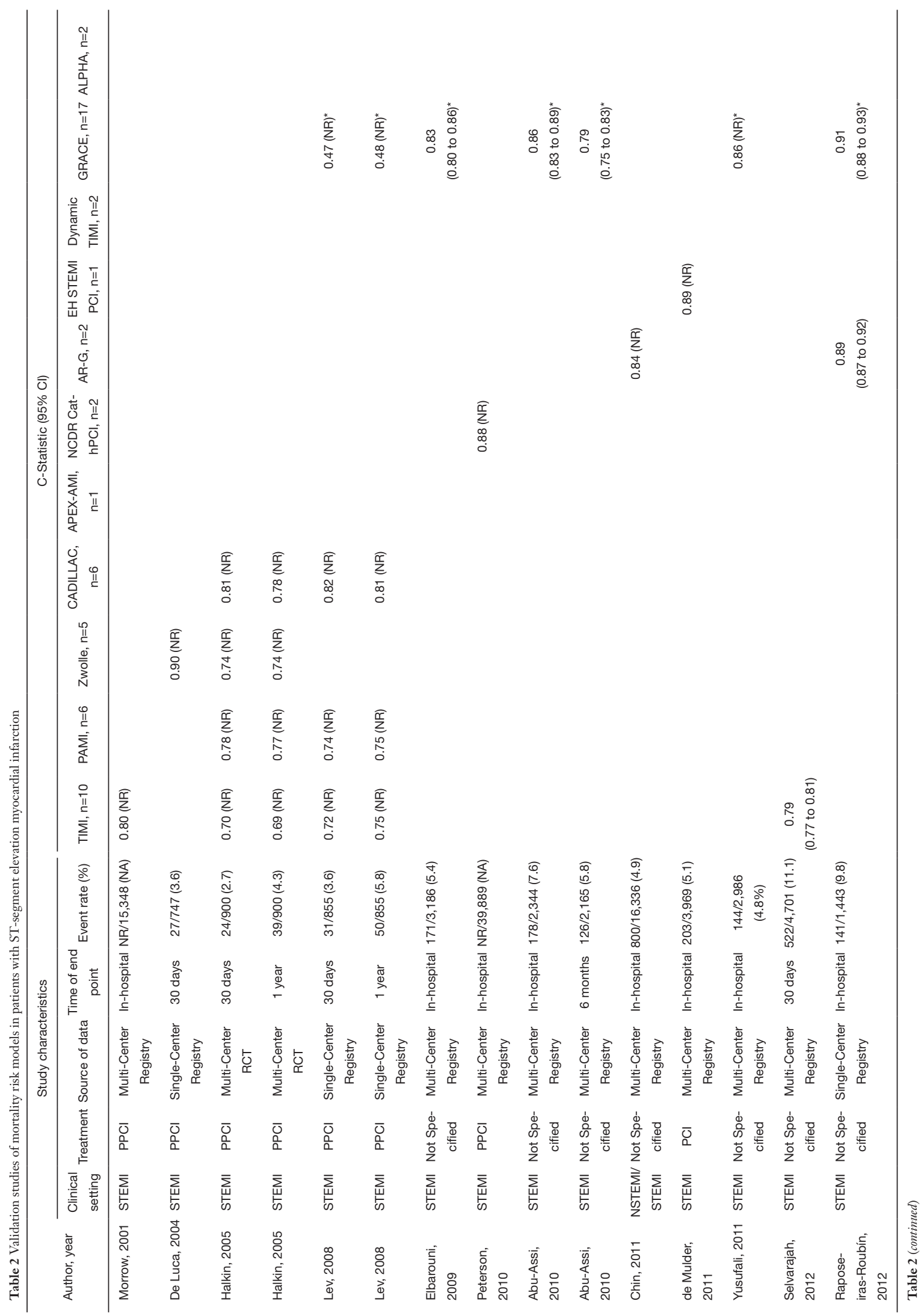




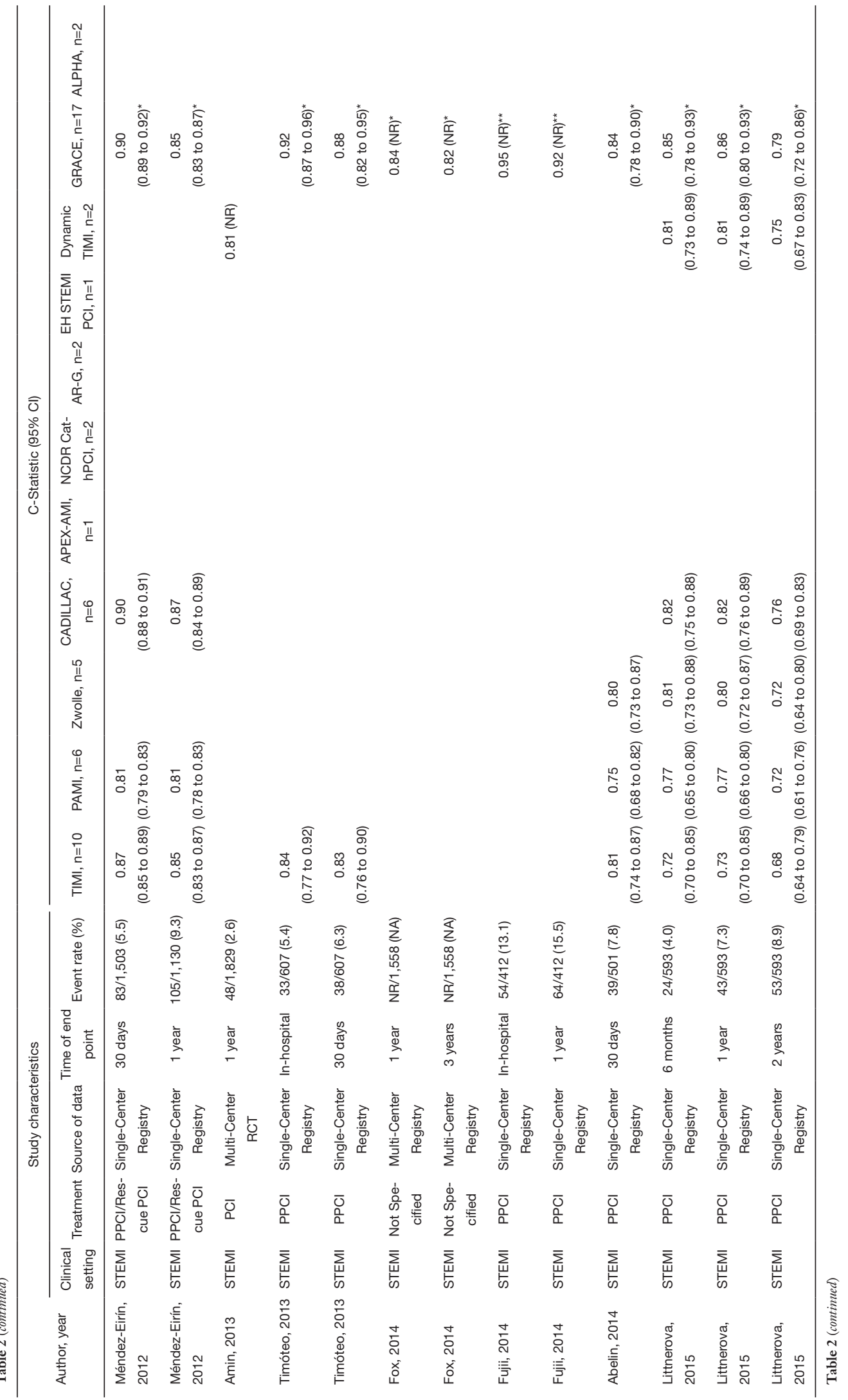




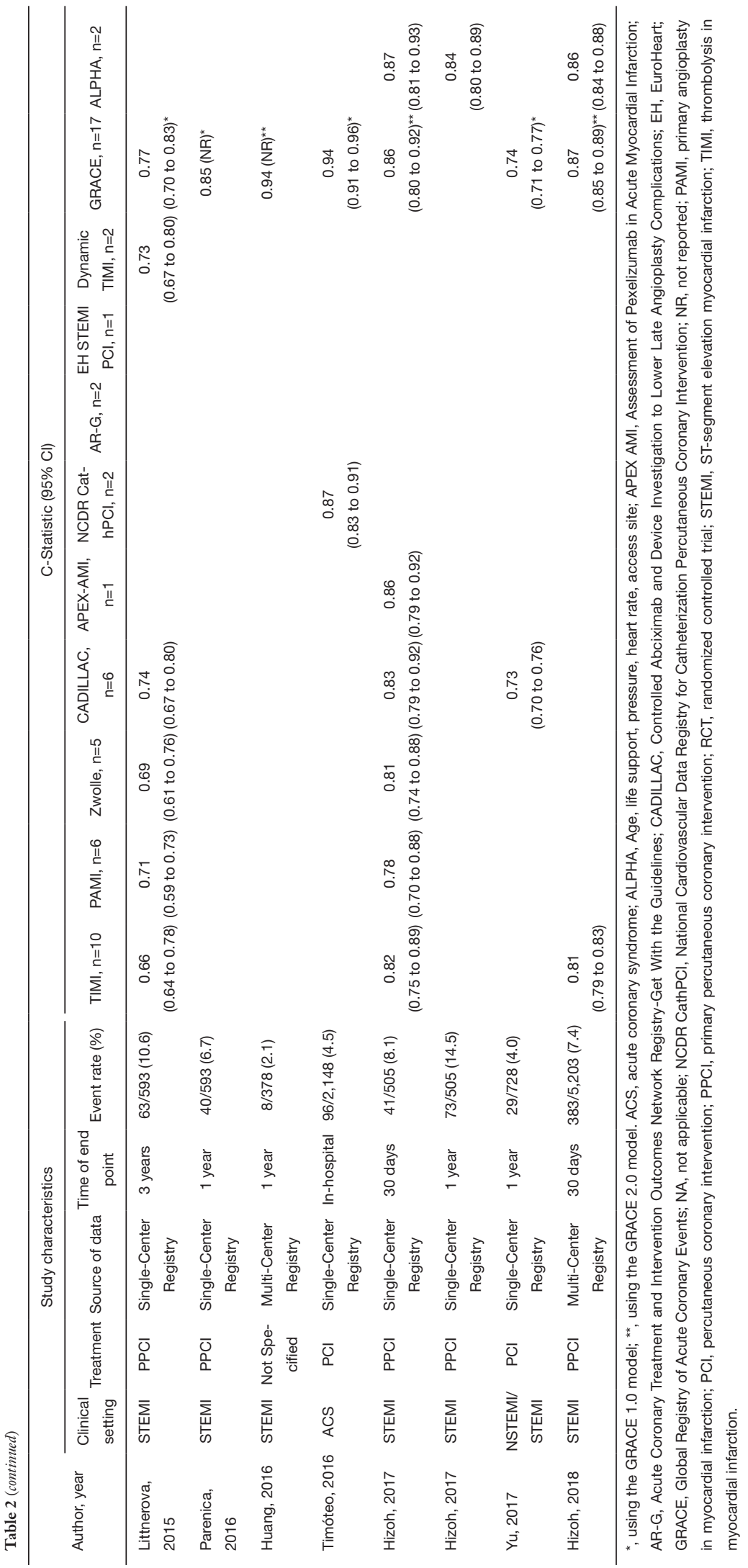


The authors regret the error.

Open Access Statement: This is an Open Access article distributed in accordance with the Creative Commons AttributionNonCommercial-NoDerivs 4.0 International License (CC BY-NC-ND 4.0), which permits the non-commercial replication and distribution of the article with the strict proviso that no changes or edits are made and the original work is properly cited (including links to both the formal publication through the relevant DOI and the license). See: https://creativecommons.org/ licenses/by-nc-nd/4.0/.

\section{References}

1. Hizoh I, Domokos D, Banhegyi G, et al. Mortality prediction algorithms for patients undergoing primary percutaneous coronary intervention. J Thorac Dis 2020;12:1706-20.

Cite this article as: Hizoh I, Domokos D, Banhegyi G, Becker D, Merkely B, Ruzsa Z. Erratum to mortality prediction algorithms for patients undergoing primary percutaneous coronary intervention. J Thorac Dis 2020;12(7):3913-3917. doi: $10.21037 /$ jtd-2020-56 